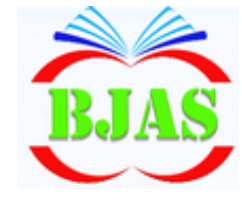

Available online at http://bajas.edu.iq

https://doi.org/10.37077/25200860.2019.253

College of Agriculture, University of Basrah
Basrah Journal of

Agricultural

Sciences

ISSN $1814-5868$

Basrah J. Agric. Sci., 32(Spec. Issue 2): 15-24, 2019

E-ISSN: 2520-0860

\title{
Response of Sorghum (Sorghum bicolor L. Moench) Genotypes to Different Levels of Agricultural Sulfur
}

\author{
Jameel, S.S. Al- Faran ${ }^{1 *} \&$ Kifah. A. Aldoghachi ${ }^{2}$ \\ ${ }^{1}$ Agriculture Directorate of Basrah, Ministry of Agriculture, Iraq \\ ${ }^{2}$ Department of Field Crops, College of Agriculture, University of Basrah, Iraq \\ *Corresponding author e-mail: jameel86822@gmail.com \\ Received 19 September 2019; Accepted 18 November 2019; Available online 22 November 2019
}

\begin{abstract}
A field experiment was conducted in agricultural research station which is located at Al-Qurna district, $75 \mathrm{~km}$ north of Basrah governorate during the autumn season 2018. The aim was to study the effect of agricultural sulfur $\left(0,3,6\right.$ and 9 t S.ha $\left.{ }^{-1}\right)$ on growth and yield of three sorghum genotypes (Inkath, Rabeh and Kafier2). The experiment was conducted as randomized complete block design in a factorial arrangement with three replications. The results showed that there were significant differences among the genotypes. The genotype kafier2 gave the highest average of plant height of $171.5 \mathrm{~cm}$ while the genotype inkath gave the highest weight of 1000 seed $(25.59 \mathrm{gm})$, grain yield $\left(3.97 \mathrm{t}^{\mathrm{n}} \mathrm{a}^{-1}\right)$. Genotype rabeh produced highest average of leaf area index and number of grain head of 3.10 and 1994.41 grain.head $^{-1}$ respectively. The agricultural sulfur showed significant effect on most studied traits of sorghum (plant height, leaf area index, grain head, weight of 1000 grains and grain yield). The addition of agricultural suffer up to $9 \mathrm{t}$. ha ${ }^{-1}$ increased grain yield and produced $5.80 \mathrm{t}^{-h a^{-1}}$. The interaction of genotypes and agricultural sulfur showed a significant effect on some traits of growth and grain yield. The genotype inkath supplied with 9 t.ha $^{-1}$ of agricultural

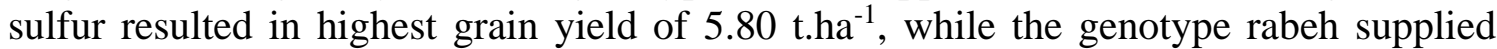
with 6 tha $^{-1}$ of agricultural sulfur gave the highest average of leaf area index (3.54) and number of grains head (2106.33 grain.head $\left.{ }^{-1}\right)$.
\end{abstract}

Keywords: Sorghum, Genotypes, Agricultural sulfur.

\section{Introduction}

Sorghum (Sorghum bicolor L.) is one of the important strategic forage and grain crop in the world, coming in fifth place after wheat, rice, maize and barley in terms of importance, cultivated area and total production, with a global world cultivated area of 41.25 million hectares and total production of 58.78 million t.ha ${ }^{-1}$. In Iraq total cultivated area in 2017 reached to $11,064 \mathrm{ha}^{-1}$ with a total production of 2943 thousand tons and average of yield reached to $1064 \mathrm{~kg} \cdot \mathrm{ha}^{-1}$ (USDA, 2018). The economic importance of sorghum it is considered as staple food for more than 750 million people, especially in Africa, Southeast Asia and Central and South America, In 


\section{Al- Faran \& Aldoghachi / Basrah J. Agric. Sci. 32(Spec. Issue 2): 15-24, 2019}

addition, it is used as a main food for humans or mixed with wheat flour by $50 \%$. The grain of sorghum contain $10 \%$ protein and $67 \%$ Carbohydrates as well as being a rich source of vitamins (Lupein, 1995). Sorghum and millited in human nutrition. (FAO Food and Nutrition series. No.27.). Sulfur is an essential element for plant growth and production. It involves in the formation of protein through the amino acids (Brosnan \& Brosnan, 2006). The study of Al-Daraji (2010) revealed that there are significant differences among four varieties of sorghum, rabeh, babylon, inkath and kafier2. The genotype kafier2 produced higher plant height of $131.90 \mathrm{~cm}$ as compared to genotype inkath, which gave the lowest rate of 110.40 $\mathrm{cm}$.

Ahmed \& Abood (2016) found in their study that the response of two cultivars of sorghum differ significantly in leaf area. The genotype rabeh gave the highest rate of leaf area reached to $4348 \mathrm{~cm}^{2}$ as compared to genotype Inkath which produced the lowest rate of $4116 \mathrm{~cm}^{2}$. El-Fahdawi \& Ali (2011) revealed that, the application of sulfur $(0,1000,2000$ and 3000 $\mathrm{kg} \cdot \mathrm{ha}^{-1}$ ) lead to significantly increase grain yield and some yield component compensation. The adding of $3000 \mathrm{~kg} \cdot \mathrm{ha}^{-1}$ to the soil gave the highest of number of grains head, the weight of 1000 grains and the grain yield of 2344 grains.head $^{-1}, \quad 26.6 \mathrm{gm}$ and 8.32 t.ha $^{-1}$ respectively. In recent study on the effect of agricultural sulfur and vitamin $\mathrm{C}$ on grain yield and yield components of maize, the results showed that the addition of $4 \mathrm{Mg} \cdot \mathrm{ha}^{-1}$ of sulfur increased protein content by $9.77 \%$ as compared to the control treatment by $9.15 \%$. (Hussein, 2016).
The present study aims the effect of agricultural sulfur on growth and yield of three sorghum genotypes.

\section{Materials \& Methods}

A field experimental study was conducted during Autumn growing season of 2018, in AlQurna Research Station of Agricultural Scientific Research, Ministry of Agriculture, located $75 \mathrm{~km}$ north of Basrah governorate to study the response of three genotype of sorghum (kafier 2, rabeh and inkath) and symbols $\left(\mathrm{V}_{1}, \mathrm{~V}_{2}\right.$ and $\left.\mathrm{V}_{3}\right)$, respectively, and for agricultural levels of sulfur $\left(0,3,6\right.$ and $9 \mathrm{t} \mathrm{S}^{\mathrm{S}} \mathrm{h}^{-}$ $\left.{ }^{1}\right)$. The soil of the experiment plowed two times vertically using Mold Board Plough, thereafter the soil was grinded using disc harrows, leveled by leveling machine. The experiment carried out using randomized complete block design (RCBD) with three replications in a factorial arrangement. The area of experimental unite was $4.0 \times 2.8 \mathrm{~m}$ contains four rows $4 \mathrm{~m}$ long with distance of $70 \mathrm{~cm}$ among rows. Within the row, a distance of $25 \mathrm{~cm}$ has been left between plant and another. In order to prevent fertilizer movement among the experimental units a distance of $2.0 \mathrm{~m}$ was left. The seeds of Sorghum sowed on 20 July, 2018 by putting 45 seeds per seed bed. 15 days after planting the seedlings were thinned to one plant, so the plant density was 57142 plant.ha ${ }^{-1}$. The agricultural sulfur (95\% sulfur) was applied one month before planting. Phosphate fertilizer applied once before planting at rate of $100 \mathrm{~kg} \cdot \mathrm{ha}^{-1}$ in form of triple superphosphate $\left(\begin{array}{lll}45 \% & \mathrm{P}_{2} \mathrm{O}_{5}\end{array}\right)$. Nitrogen fertilizer was added at a rate of 200 $\mathrm{kg} \cdot \mathrm{ha}^{-1}$ in the form of urea $(46 \% \mathrm{~N})$. Urea fertilizer was added in two times, the first one at planting, whereas the second one after 30 days from planting (Ali, 2012). The following 
Al- Faran \& Aldoghachi / Basrah J. Agric. Sci. 32(Spec. Issue 2): 15-24, 2019

characteristics were measured: plant height, leaf area index, number of grains head, weight of 1000 grains and grain yield. Data were analyzed statistically according to the design used in the experiment, the average of traits were tested by using least significant differences (L.S.D.) at probability level $0.05 \mathrm{El}-$ Sahoki \& Wahib (1990).

Table (1) some physical chemical properties of the soil before planting.

\begin{tabular}{|c|c|c|c|c|c|c|c|}
\hline Texture & S & $\mathrm{K}$ & $\mathrm{P}$ & $\mathrm{N}$ & \multirow{2}{*}{$\begin{array}{l}\text { Organic matter } \\
\qquad\left(\mathrm{gm} \mathrm{kg}^{-1}\right)\end{array}$} & \multirow{2}{*}{ E.C. $\left(\mathrm{dsm}^{-1}\right)$} & \multirow{2}{*}{$\mathrm{pH}$} \\
\hline & \multicolumn{4}{|c|}{ soil $\left(\mathrm{mg} \mathrm{kg}^{-1}\right)$} & & & \\
\hline Silty loam & 95.20 & 166 & 19.80 & 22.27 & 1.82 & 3.52 & 7.45 \\
\hline
\end{tabular}

\section{Results \& Discussion}

\section{Plant height (cm)}

The results of analysis of variance (Table 7) showed that there were highly significant differences of genotypes and agricultural sulfur in plant height. The results of table (2) revealed that the genotype $V_{1}$ gave the highest average of plant height of $171.5 \mathrm{~cm}$, while the genotype $\mathrm{V}_{3}$ gave the lowest rate
$(121.08 \mathrm{~cm})$. The differences among genotype in plant height could be attributed to the genetic differences between the genotype and their responses to environment. This result is in consistent with Yaqoob et al. (2015) and Attiya (2015). The results indicated in table (2) revealed a significant effect for agricultural sulfur in plant height.

Table (2): Effect of sorghum genotypes, agricultural sulfur and their interaction on plant height (cm).

\begin{tabular}{|c|c|c|c|c|c|}
\hline \multirow{2}{*}{$\begin{array}{l}\text { Sorghum } \\
\text { genotypes }\end{array}$} & \multicolumn{4}{|c|}{ Agricultural sulfur levels t S.ha ${ }^{-1}$} & \multirow{2}{*}{$\begin{array}{l}\text { Genotypes } \\
\text { mean }\end{array}$} \\
\hline & $\mathrm{S}_{0}$ & $\mathrm{~S}_{1}$ & $\mathrm{~S}_{2}$ & $\mathrm{~S}_{3}$ & \\
\hline $\mathrm{V}_{1}$ & 160.33 & 169.67 & 175.66 & 180.33 & 171.50 \\
\hline $\mathrm{V}_{2}$ & 123.50 & 131.00 & 141.33 & 150.00 & 136.45 \\
\hline $\mathrm{V}_{3}$ & 102.66 & 119.00 & 127.67 & 135.00 & 121.08 \\
\hline Mean sulfur & 128.83 & 139.89 & 148.22 & 155.11 & \\
\hline \multirow{2}{*}{ L.S.D (0.05) } & Genotypes & $\begin{array}{c}\text { agricultural } \\
\text { sulfur levels }\end{array}$ & \multicolumn{2}{|c|}{$\begin{array}{c}\text { agricultural sulfur X } \\
\text { Genotypes }\end{array}$} & \\
\hline & 3.41 & 3.93 & \multicolumn{2}{|c|}{ N.S } & \\
\hline
\end{tabular}


The addition of $\mathrm{S}_{3}$ level lead to produced highest plant height of $155.11 \mathrm{~cm}$ compared to control treatment $\mathrm{S}_{0}$, which gave the lowest rate of $128.83 \mathrm{~cm}$. These results are consistent with Zeboon \& Al-Hilfy (2014) and Kadhim (2016).

\section{Leaf area index}

The results of analysis of variance (Table 7) indicated that there is high significant differences on the genotypes, agricultural sulfur and their interaction. The results of Table (3) revealed that the genotype $\mathrm{V}_{2}$ (rabeh) gave the highest leaf area index of 3.10 while genotype $\mathrm{V}_{1}$ (kafier2) gave the lowest leaf area index of 2.35. The differences among the genotypes in leaf area index could be related to the genetic differences between the genotypes, so this revealed that $\mathrm{V}_{2}$ was more adapted to the local environmental condition as compared to other genotypes. These results are consistent with AlJubory \& Al-Zubaidy (2013) \& Ali et al. (2017). The results of table (3) revealed a significant effect foragricultural sulfur in leaf area index. The $S_{3}$ treatment gave the highest value of this characteristic (3.18) compared to the control $\left(\mathrm{S}_{0}\right)$, which gave the lowest rate leaf area index (2.34). These results are consistent with Hamza \& Al-Amri (2007), El-Fahdawi \& Ali (2011) and Zeboon \& Al-Hilfy (2014). The results of table (3) indicated a significant interaction among genotypes and the levels of agricultural sulfur. The genotype $\mathrm{V}_{2}$ under the level $\mathrm{S}_{3}$ of agricultural sulfur gave the highest rate of the leaf area index of 3.54, while the genotype $\mathrm{V}_{1}$ under $\mathrm{S} 0$ agricultural sulfur gave the lowest leaf area index of 2.05. This type of response is due to the effect of single factors.

\section{Grain numbers head}

The results of analysis of variance (Table 7) showed that there is high significant differences between the genotypes, agricultural sulfur and their interaction. The results of table (4) indicated that genotype $V_{2}$ gave the highest average of grain number head of (1994.41 grain.head $^{-1}$ ) as compared to the genotype $\mathrm{V}_{1}$ which gave the lowest average of (1436.91 grain.head $\left.{ }^{-1}\right)$. The differences between the genotypes may be due to the difference in genetic traits for each genotype and thus the

Table (3): Effect of sorghum genotypes and agricultural sulfur and their interaction on leaf area index.

\begin{tabular}{|c|c|c|c|c|c|}
\hline \multirow{2}{*}{$\begin{array}{l}\text { Sorghum } \\
\text { genotypes }\end{array}$} & \multicolumn{4}{|c|}{ Agricultural sulfur levels t S.ha ${ }^{-1}$} & \multirow{2}{*}{$\begin{array}{l}\text { Genotypes } \\
\text { mean }\end{array}$} \\
\hline & $\mathrm{S}_{0}$ & $\mathrm{~S}_{1}$ & $\mathrm{~S}_{2}$ & $\mathrm{~S}_{3}$ & \\
\hline $\mathrm{V}_{1}$ & 2.05 & 2.25 & 2.36 & 2.75 & 2.35 \\
\hline $\mathrm{V}_{2}$ & 2.59 & 2.90 & 3.35 & 3.54 & 3.10 \\
\hline $\mathrm{V}_{3}$ & 2.37 & 2.54 & 2.57 & 3.25 & 2.68 \\
\hline Mean sulfur & 2.34 & 2.56 & 2.76 & 3.18 & \\
\hline \multirow{2}{*}{ L.S.D $(0.05)$} & Genotypes & $\begin{array}{l}\text { agricultural } \\
\text { sulfur levels }\end{array}$ & \multicolumn{2}{|c|}{$\begin{array}{l}\text { agricultural sulfur X } \\
\text { Genotypes }\end{array}$} & \\
\hline & 0.04 & 0.05 & \multicolumn{2}{|c|}{0.09} & \\
\hline
\end{tabular}


number of flowers formed, which reflected in grains number head. These results are in consistent with results of Abdul-Hameed (2016) and Abood et al. (2017). The results presented in table (4) displayed a significant effect for the addition of agricultural sulfur in grains number.head ${ }^{-1}$. The application of $\mathrm{S}_{3}$ produced highest average of grains number per head of 2001.10 grain.head $^{-1}$ with an increase reached to 367.17 grain.head $^{-1}$ as compared to the control $\left(\mathrm{S}_{0}\right)$. The control treatment $\left(\mathrm{S}_{0}\right)$ produced the lowest average (1633.93 grain.head $\left.^{-1}\right)$.This is consistent with results of Joel et al. (2018) and Hussein (2016). The data in of table (4) exhibited a significant interaction between genotype and agricultural sulfur, the interaction $\mathrm{V}_{2} \times \mathrm{S}_{3}$ gave the highest average of grain head of 2106.33 grain.head $^{-1}$, while the interaction of $V_{1} \times S_{0}$ gave the lowest average of the grain head reached to 1076.66 grain.head $^{-1}$. This type of response was due to the effect of single factors.

Table (4): Effect of sorghum genotypes, agricultural sulfur and their interaction on grain number head.

\begin{tabular}{cccccc}
\hline \multirow{2}{*}{$\begin{array}{c}\text { Sorghum } \\
\text { genotypes }\end{array}$} & \multicolumn{4}{c}{ Agricultural sulfur levels t S.ha ${ }^{-1}$} & \multirow{2}{*}{$\begin{array}{c}\text { Genotypes } \\
\text { mean }\end{array}$} \\
\cline { 2 - 5 } $\mathrm{S}_{0}$ & 1076.66 & 1330.33 & 1480.66 & 1860.00 & 1436.91 \\
\hline $\mathrm{V}_{1}$ & 1995.66 & 1920.66 & 1955.00 & 2106.33 & 1994.41 \\
\hline $\mathrm{V}_{2}$ & 1829.46 & 1925.00 & 1937.33 & 2036.66 & 1932.11 \\
\hline $\mathrm{V}_{3}$ & 1633.93 & 1725.33 & 1791.10 & 2001.10 \\
\hline Mean sulfur & Genotypes & $\begin{array}{c}\text { agricultural } \\
\text { sulfur levels }\end{array}$ & $\begin{array}{c}\text { agricultural sulfur X } \\
\text { Genotypes }\end{array}$ \\
\cline { 2 - 5 } L.S.D (0.05) & 55.91 & 64.57 & \multicolumn{2}{c}{111.83} \\
\end{tabular}

\section{Weight of 1000 grain (g)}

The results of analysis of variance (Table 7) demonstrated that there is high significant differences among the genotypes and agricultural sulfur in grain number head. While the interaction of genotypes and agricultural sulfur has significant effect. The results of table (5) indicated that the genotypes $\mathrm{V}_{1}$ gave the highest average of 1000 grains weight reached to 25.74 gm as compared to the genotype $\mathrm{V}_{2}$ which gave the lowest average of $23.50 \mathrm{gm}$. The differences 
between the genotypes may be due to the difference in genetic ability and so to the genotype response to environment. This results is consistent with the findings of Solag \& Al-Ani (2011), Abdullah et al. (2012) and Al-Maeini \& Al-Issawi (2017).

The results indicated in table (5) revealed that the addition of agricultural sulfur lead to increase the weight of 1000 grain, the treatment of $\mathrm{S}_{3}$ gave the lowest rate of weight of 1000 grain of $24.30 \mathrm{gm}$, while the $S_{0}$ (control treatment) gave the highest rate of this trait reached to $25.80 \mathrm{gm}$. The addition of agricultural sulfur lead to increase grain number head (see table 4) so this lead to increase the competition between formatting grains on photosynthesis product within the head, which reflect negatively on weight of 1000 grain. These results are consistent with the findings of El-Fahdawi (2008); Al-Jubory (2011) and Kadhim (2016). The results table (5) revealed a significant interaction between the genotype and agricultural sulfur, the interference of $\mathrm{V}_{1} \times \mathrm{S}_{0}$ gave the highest rate of weight of 1000 grain of $26.92 \mathrm{gm}$, while the interference of $\mathrm{V}_{2} \times \mathrm{S}_{3}$ gave the lowest weight of 1000 grain of $23.17 \mathrm{gm}$.

\section{Grain yield (t.ha ${ }^{-1}$ )}

The results of analysis of variance (Table 7) revealed that there is high significant differences between genotypes, agricultural sulfur and their interaction in grain yield. The results of table (6) displayed that the genotype $\mathrm{V}_{3}$ produced the highest rate of grain yield of (4.97 t.ha- ${ }^{-1}$, while, the genotype $\mathrm{V}_{1}$ produced the lowest grain yield of (3.59 tha $\left.{ }^{-1}\right)$. The reason of increase grain yield in sorghum could be due to the difference in some growth characteristics such as plant height, grain number head and weight of 1000 grain, the results are consistent with previous results obtained by AghaAlikhani et al. (2012) and Attia (2016).

Table (5): Effect of sorghum genotypes, agricultural sulfur and their interaction on weight of 1000 grain (gm)

\begin{tabular}{cccccc}
\hline \multirow{2}{*}{$\begin{array}{c}\text { Sorghum } \\
\text { genotypes }\end{array}$} & \multicolumn{4}{c}{ Agricultural sulfur levels t S.ha ${ }^{-1}$} & \multirow{2}{*}{$\begin{array}{c}\text { Genotypes } \\
\text { mean }\end{array}$} \\
\cline { 2 - 5 } & $\mathrm{S}_{0}$ & $\mathrm{~S}_{1}$ & $\mathrm{~S}_{2}$ & $\mathrm{~S}_{3}$ & 25.74 \\
\hline $\mathrm{V}_{1}$ & 26.92 & 25.92 & 25.63 & 24.50 & 23.50 \\
\hline $\mathrm{V}_{2}$ & 24.16 & 23.39 & 23.27 & 23.17 & 25.59 \\
\hline $\mathrm{V}_{3}$ & 26.31 & 25.48 & 25.35 & 25.24 & \\
\hline Mean sulfur & 25.79 & 24.93 & 24.75 & 24.30 & \\
\hline \multirow{2}{*}{ L.S.D (0.05) } & Genotypes & $\begin{array}{c}\text { agricultural } \\
\text { sulfur levels }\end{array}$ & $\begin{array}{c}\text { agricultural sulfur X } \\
\text { Genotypes }\end{array}$ & \\
\cline { 2 - 5 } & 0.09 & 0.10 & \multicolumn{2}{c}{0.18} \\
\hline
\end{tabular}


The results presented in table (6) revealed that the addition of agricultural sulfur lead to increased grain yield. The highest level of agricultural sulfur $\left(\mathrm{S}_{3}\right)$ significantly increased grain yield and gave (5.10 t.ha $\left.{ }^{1}\right)$, while the control treatment $\mathrm{S}_{0}$ gave the lowest grain yield of $\left(3.76\right.$ t.ha $\left.^{-1}\right)$. The grain yield is an indicator for his components; these results are consistent with Al-Zubaidi et al. (2016), Hussein (2016) and Al-Tamimi et al. (2018). The results of table (6) indicated that there was significant interaction for the factors,. The interaction of $\mathrm{V}_{3} \times \mathrm{S}_{3}$ gave the highest rate of yield reached to $5.80 \mathrm{t}^{\mathrm{h} \mathrm{h}^{-1}}$ as compared to the interaction of $\mathrm{V}_{1} \times \mathrm{S}_{0}$ which gave the lowest grain yield of 3.31 t.ha' ${ }^{-1}$.

The addition of agricultural sulfur lead to reduce the value of $\mathrm{pH}$ in soil and increase the availability of nutrients which led to the improve plant growth, moreover lead to increase grain number head (see table 4) which reflect positively to increase grain yield.

Table (6): Effect of sorghum genotypes, agricultural sulfur and their interaction on grain yield (t.ha-1).

\begin{tabular}{|c|c|c|c|c|c|}
\hline \multirow{2}{*}{$\begin{array}{l}\text { Sorghum } \\
\text { genotypes }\end{array}$} & \multicolumn{4}{|c|}{ agricultural sulfur levels t S.ha-1 } & \multirow{2}{*}{$\begin{array}{l}\text { Genotypes } \\
\text { mean }\end{array}$} \\
\hline & $\mathrm{S}_{0}$ & $\mathrm{~S}_{1}$ & $\mathrm{~S}_{2}$ & $\mathrm{~S}_{3}$ & \\
\hline $\mathrm{V}_{1}$ & 3.31 & 3.60 & 3.46 & 4.01 & 3.59 \\
\hline $\mathrm{V}_{2}$ & 3.53 & 4.42 & 4.59 & 5.50 & 4.51 \\
\hline $\mathrm{V}_{3}$ & 4.45 & 4.65 & 5.00 & 5.80 & 4.97 \\
\hline Mean sulfur & 3.76 & 4.22 & 4.35 & 5.10 & \\
\hline \multirow[t]{2}{*}{ L.S.D $\quad(0.05)$} & Genotypes & $\begin{array}{l}\text { agricultural } \\
\text { sulfur levels }\end{array}$ & \multicolumn{2}{|c|}{$\begin{array}{l}\text { agricultural sulfur X } \\
\text { Genotypes }\end{array}$} & \\
\hline & 0.05 & 0.06 & \multicolumn{2}{|c|}{0.11} & \\
\hline
\end{tabular}


Al- Faran \& Aldoghachi / Basrah J. Agric. Sci. 32(Spec. Issue 2): 15-24, 2019

Table (7): Analysis of variance represented

by mean square of traits measured.

\section{Reference}

Abdul-Hameed, Z.A. (2016). Sorghum

\begin{tabular}{|c|c|c|c|c|}
\hline $\begin{array}{c}\text { Sources of } \\
\text { variation }\end{array}$ & df & Plant height & $\begin{array}{l}\text { Leaf area } \\
\text { index }\end{array}$ & 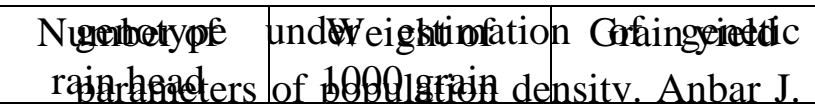 \\
\hline Replicates & 2 & $391.132 * *$ & $0.050^{*}$ & 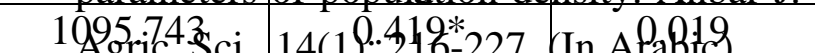 \\
\hline $\begin{array}{l}\text { Agricultura } \\
1 \text { sulfur }(S)\end{array}$ & 3 & $1152.970 * *$ & $1.145 * *$ & $\begin{array}{l}\text { 219124.543** } \\
\text { Abdullah, B.H.; Ali, S.N. \& Ajaj, H.A. }\end{array}$ \\
\hline $\begin{array}{l}\text { Genotypes } \\
(\mathrm{V})\end{array}$ & 2 & $8012.299 * *$ & $1.662 * *$ & 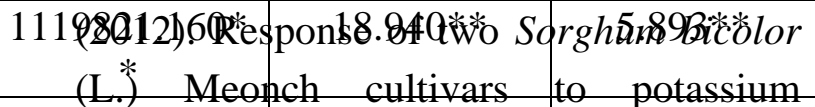 \\
\hline $\begin{array}{l}\text { Sorghum } \times \\
\text { agricultural } \\
\text { sulfur }\end{array}$ & 6 & 27.928 & $0.058 *$ & $\begin{array}{l}71997160 * * \text { and } 0.383^{*} \text { distance between rows. } \\
\text { fertilizer and } \\
\text { Anbar J. Agric. Sci., 10(1): 273- 296. (In }\end{array}$ \\
\hline Error & 22 & 23.677 & 0.005 & 63644.9iG2. \\
\hline Total & 35 & & & \\
\hline
\end{tabular}

* means significant differences was found among the treatment at 0.05 level.

** means significant differences was found among the treatment at 0.01 level.

\section{Conclusions}

The results showed the superiority of genotype Inkath in grain yield (4.97 t.ha-1). Therefore, the genotype Inkath is more suitable planted in local environmental condition and to cultivated in this area. The addition of agricultural sulfur lead to improve Sorghum growth and productivity. The level of 9 t.ha ${ }^{-1}$ produced the highest grain yield of 5.10 t.ha $^{-1}$. The interaction had a significant effect on the grain yield, the genotype Inkath gave the highest grain yield at $9 \mathrm{t}^{-h^{-1}}$ of agricultural sulfur reached to 5.80 t.ha $^{-1}$.

\section{Acknowledgements}

The authors would like to thanks Department of Field Crops, College of Agriculture, University of Basrah especially Assis. Prof. Dr. Kareem H. Mohsin, and Assis. Prof. Dr. Sundus A. Mohammed for their providing and supporting. We also wish to thanks and appreciate Dr. Kadhim H. Huthily for his help in data analysis and scientific advises.
H.S. (2017). Effect of bio fertilizer concentrations on qualitative and quantitative traits of three cultivars of Sorghum bicolor (L.) Meonch. Anbar J. Agric. Sci., 15(2): 430-442. (In Arabic).

AghaAlikhani, M.; Etemadi, F. \& Ajirlo, A.F. (2012). Physiological basis of difference in grain sorghum (Sorghum bicolor L. Moench) in a semi-arid environment. ARPN. J. Agric. Biol. Sci., 7(7): 488-496.

Ahmed, Y.A.A. \& Abood, N.M. (2016). Response of two varieties of sorghum (Sorghum bicolor L. Meonch) to plant density. Anbar J. Agric. Sci., 14(2): 188203. (In Arabic).

Al-Daraji, Z.A. (2010). Response of some sorghum genotypes (Sorghm bicolor L. Meonch) for levels of potassium fertilizer. Anbar J. Agric. Sci., 8(4): 491-502. (In Arabic).

Ali, A.M.; Khalaif, O.I. \& Hemdian, M.I. (2017). Effect of electric shock on growth characteres yield and yield component of two varieties of Sorghum bicolor (L.) Meonch. Anbar J. Agric. Sci., 15(1): 143-

Ali, N.S. (2012). Fertilizer Technologies and Their Uses. Min. High. Educ. Sci. Res. 151. (In Arabic). 


\section{Al- Faran \& Aldoghachi / Basrah J. Agric. Sci. 32(Spec. Issue 2): 15-24, 2019}

Univ. House for Printing and Publishing. Univ. Baghdad: 121pp. (In Arabic).

Al-Jubory, A.A.J.J. (2011). Effect of sources and levels of magnesium and potassium sulfate on growth and yield of maize (Zea mays L.) and their nutrient content. M. Sc. Thesis. Coll. Agric., Univ. Baghdad: 93pp. (In Arabic).

Al-Jubory, R.K. \& Al-Zubaidy, S.A. (2013). Effect of plant densities on growth and fodder yield of two cultivars of sorghum (Sorghm. bicolor L. Meonch). Al-Furat J. Agric. Sci., 5(2): 167-175. (In Arabic).

Al-Maeini, W.K.A. \& Al-Issawi, Y.J.A. (2017). Effects of foliar application of yeast extract on seed yield and seed yield components of five sorghum cultivars (Sorghum bicolor L. Meonch). Anbar J. Agric. Sci., 15(1): 152-161. (In Arabic).

Al-Tamimi, H.J.H.; Amiri, N.J.M. \& Hassan, M.J. (2018). Effect of selenium, sulfur and phosphorus fertilization on the dry weight of vegetative total of (Zea mays L.) cultivated in different soils. Syri J. Agric. Res., 5(2): 190-202. (In Arabic).

Al-Zubaidi, R.A.O.; Haifa, J.H. \& Thaher, A.T. (2016). Effect of agricultural sulfur and concentrated superphosphate concentrate on soil phosphorus availability and its concentration in leaves of sorghum (Sorghum bicolor L. Meonch) at different growth periods. Thi-Qar J. Agric. Sci., 5(1): 85-94. (In Arabic).

Attia, M.A. (2016). Performance of some sorghum genotypes under salinity conditions. IOSR J. Agric. Sci., 9(4): 8-12. (In Arabic).

Attiya, R.L. (2015). Effect of different concentrations of gibberellic acid (GA3) on growth and yield of some cultivars Sorghum bicolor (L.) Meonch. Al-Furat J. Agric. Sci., 7(3): 157-163. (In Arabic).

Brosnan, J.R. \& Brosnan, M.E. (2006). The sulfur-containing amino acids: an overview. J. Nutr., 136(6): 1636-1640.

El-Fahdawi, W.A.T. (2008). Effect of agriculture sulfur and DAP fertilizer levels on grain yield and its components of sorghum [Sorghum bicolor (L.) Moench]. M. Sc. Thesis. Coll. Agric., Univ. Baghdad: 79pp. (In Arabic).

El-Fahdawi, W.A.T. \& Ali, K.L.M. (2011). Effect of sulfur and DAP fertilizer on grain yield and its components of sorghum. Iraqi J. Dese. Stud., 3(1): 57-62. (In Arabic).

El-Sahoki, M. \& Wahib, K.M. (1990). Applications in the design and analysis of experiments. Min. High. Educ. Sci. Res. Baghdad University. Dar Al Hekma Printing Press. Connector: 488pp. (In Arabic).

Hamza, J.H. \& Al-Amri, M.M. (2007). Response of growth and yield of maize (Zea mays L.) to potassium and sulfur fertilizers interaction. Qadis. J. Agric. Sci., 12(2): 1-14. (In Arabic).

Hussein, H.T. (2016). Effect of sulfur and vitamin $\mathrm{C}$ on some vegetative growth characters of corn crops (Zea mays L.). Karbala J. Agric. Sci., 14(3): 81-88. (In Arabic).

Joel, J.D.A.; Francisco, J.M.D.O.; Luiz, G.M.P.; Simone, A.D.S.N. \& Eduardo, S.D.S. (2018). Effects of elemental sulfur associated with gypsum on soil salinity attenuation and sweet sorghum growth under saline water irrigation. Australian J. Crop Sci., 12(2): 221-226. 
Al- Faran \& Aldoghachi / Basrah J. Agric. Sci. 32(Spec. Issue 2): 15-24, 2019

Kadhim, A.H. (2016). Role of agricultural sulfur applied at different rates and times on soil the degree of soil $\mathrm{pH}$, availability of some micronutrients, growth and yield of two wheat cultivars (Triticum aestivum L.). M. Sc. Thesis. Coll. Agric., Univ. Muthanna: 119pp. (In Arabic).

Lupein, J.R. (1995). Sorghum and millited in human nutrition. FAO Food and Nutrition series. 27pp.

Solag, B.H.A. \& Al-Ani, A.A.G.H. (2011). Effect of foliar application of zinc and potassium fertilization on growth and yield and quality characteristics of two varieties of Sorghum bicolor (L.) Moench. Anbar J. Agric. Sci., 9(2): 117-135. (In Arabic).
USDA. (2018). World agriculture production, foreign agriculture service, office of global analysis, Washington, Circular Series WAP: 18pp.

Yaqoob, M.; Hussain N. \& Rashid A. (2015). Genetic variability and heritability analysis for yield and morphological traits in sorghum (Sorghum bicolor L. Moench) genotypes. J. Agric. Res., 53(3): 331-341.

Zeboon, N.H. \& Al-Hilfy, I.H. (2014). Effect of sulfur and npk fertilizer on npk concentration in wheat leaves and grains. Iraqi J. Agric. Sci., 45(7): 700-707. (In Arabic). 